\title{
PERBANDINGAN ABNORMAL RETURN DAN LIKUDITAS SAHAM SEBELUM DAN SEDUDAH STOCK SPLIT: STUDI PADA PERUSAHAAN YANG TERDAFTAR DI BURSA EFEK INDONESIA
}

\author{
Kornel Munthe \\ Fakultas Ekonomi Universitas Katolik Santo Thomas \\ E-mail: munthe_kornel@yahoo.com
}

\begin{abstract}
The main objective of this research is know the differences in abnormal returns and liquidity of shares before-after stock split at companies listed Indonesian Stock Exchange during the period of 2011-2014. By using purposive sampling method then selected 24 samples of companies that meet the criteria. The period of observation for 5 days before - 5 days after stock split. Test of Wilcoxon Signed Rank showed significant the difference in average abnormal returns and liquidity of shares before- after stock split, this indicates that the market reacted positively to the stock split.
\end{abstract}

Keywords: stock split, abnormal return, liquidity of shares.

Abstrak: Tujuan dari penenilitan ini adalah unutk mengetahui perbedaan abnormal return dan likuiditas saham sebelum dan sesudah stock split pada perusahaan yang terdaftar di Bursa Eefek Indonesia periode 2011-2014. Dengan menggunakan metode purposive sampling maka dipilih 24 sampel perusahaan yang memenuhi kriteria. Periode pengamatan selama 5 hari sebelum dan 5 hari sesudah stock split. Uji Wilcoxon Signed Rank menunjukkan adanya perbedaan yang signifikan rata-rata abnormal return dan likuiditas saham sebelum dan sesudah stock split, hal ini mengindikasikan bahwa pasar bereaksi positif atas stock split.

Kata Kunci: stock split, abnormal return, likuiditas saham.

\section{PENDAHULUAN}

Sebagai bagian dari sistem perekonomian pasar modal dalam melaksanakan fungsi ekonominya dapat mempertemukan pihak yang membutuhkan dana jangka panjang yakni pihak emiten dengan pihak investor yang membutuhkan sarana investasi terpercaya dan prospektif. Investor dalam menentukan dan memilih pada perusahaan mana mereka akan menginvestasikan modalnya dengan tujuan memperoleh keuntungan maksimal melalui permintaan dan penawaran saham yang terjadi. Salah satu faktor yang mempengaruhi besarnya permintaan dan penawaran saham adalah tingkat harga saham tersebut. Apabila suatu saham harganya dinilai terlalu tinggi maka jumlah permintaan akan saham tersebut akan berkurang dan sebaliknya banyak investor akan berusaha menjual saham mereka. Begitupun sebaliknya, apabila investor menilai harga suatu saham terlalu rendah, maka investor akan berlomba-lomba untuk membeli saham tersebut sehingga permintaan akan menjadi meningkat. Persepsi investor terhadap kewajaran harga suatu saham akan menentukan keseimbangan penawaran dan permintaan saham. Harga saham yang dinilai terlalu mahal oleh investor akan mengurangi minat konsumen untuk membeli saham tersebut. Untuk menarik minat investor, perusahaan perlu mempertahankan harga saham mereka pada rentang yang wajar dan ideal menurut para investor sehingga saham tersebut cukup likuid untuk diperdagangkan. 
Para investor yang bertransaksi di pasar modal sebelum membuat suatu keputusan dalam memilih portofolio investasi yang menguntungkan, maka para investor memerlukan berbagai informasi. Salah satu informasi yang tersedia adalah pengumuman stock split atau pemecahan saham. Pemecahan saham merupakan aktivitas yang dilakukan oleh perusahaan yang go publik untuk menaikkan jumlah saham yang beredar dimana aktivitas tersebut biasanya dilakukan pada saat harga saham dinilai terlalu tinggi sehingga kemampuan investor untuk membelinya menjadi menurun. Pengumuman pemecahan saham dianggap sebagai informasi yang berarti oleh investor untuk melakukan keputusan. Dengan pemecahan saham maka harga saham akan menjadi lebih rendah sehingga akan lebih mudah dijangkau oleh investor kecil, hal ini akan menimbulkan permintaan saham meningkat dan saham akan menjadi lebih likuid.

Oleh karena itu salah satu alasan perusahaan untuk melakukan pemecahan saham disebabkan harga saham yang terlalu tinggi sehingga menurunkan tingkat permintaan dan kemampuan investor untuk dapat membeli saham tersebut. Tingkat harga saham berpengaruh pada tingginya permintaan dan penawaran akan saham tersebut. Harga suatu saham yang terlalu tinggi maka akan menyebabkan jumlah permintaan terhadap saham tersebut akan berkurang, sehingga kemampuan investor untuk membeli saham tersebut berkurang. Pemecahan saham merupakan salah satu cara yang dilakukan emiten untuk menjaga agar harga saham tetap berada berada pada kisaran perdagangan yang maksimal, sehingga para calon investor masih memiliki daya beli terhadap saham tersebut. Pada umumnya perusahaan yang melakukan pemecahan saham merupakan perusahaan yang mempunyai kinerja baik, hal tersebut bisa dilihat dari harga saham yang tinggi (Fahmi, 2012). Pemecahan saham akan menyebabkan harga saham menjadi lebih rendah sehingga calon investor kecil dapat menjangkau harga saham, kemudian sesudah pemecahan saham tersebut akan berdampak pada permintaan yang semakin meningkat akibatnya saham akan menjadi lebih likuid. Stock split merupakan strategi perusahaan yang dilakukan di pasar modal untuk menarik minat calon investor. Beberapa alasan mengapa manajer perusahaan melakukan stock split adalah: (1) Agar harga saham tidak terlalu mahal sehingga dapat meningkatkan jumlah pemegang saham dan meningkatkan likuiditas perdagangan saham, (2) Untuk mengembalikan harga dan ukuran perdagangan rata-rata saham kepada kisaran yang telah ditargetkan, dan (3) Untuk membawa informasi mengenai kesempatan investasi yang berupa peningkatan laba dan deviden kas. (Scot, Martin, Petty dan Kewon dalam Fahmi,2012)

Pemecahan saham mengakibatkan harga saham menjadi lebih murah sehingga akan menarik calon investor untuk membeli saham tersebut. Menurut Brigham and Gapenski (1996), semakin banyak investor yang melakukan transaksi terhadap saham tersebut maka volume perdagangan saham akan meningkat. Volume perdagangan saham merupakan salah satu indikator yang dapat digunakan untuk melihat reaksi pasar terhadap suatu informasi berkaitan dengan suatu saham. Likuiditas saham adalah kemampuan membeli dan menjual sekuritas saham secara lebih cepat pada harga yang telah diketahui dapat diukur Trading Volume Activity. (Reily dan Brown, 2009). Perubahan volume perdagangan saham diukur dengan Trading Volume Activity (TVA). TVA merupakan perbandingan antara jumlah saham perusahaan yang diperdagangkan pada periode tertentu dengan jumlah saham perusahaan yang beredar pada periode tertentu. Besar kecilnya perubahan rata-rata TVA sebelum dan sesudah pemecahan sahan merupakan ukuran besar kecilnya akibat yang ditimbulkan dari informasi pemecahan saham. Harga saham yang tinggi tidak mampu dijangkau oleh calon investor maka dilakukanlah pemecahan saham oleh 
perusahaan. Jika harga saham menjadi lebih murah maka ada kemungkinan akan menyebabkan transaksi terhadap saham tersebut meningkat sehingga harga saham sering berubah dan dapat memberikan peluang untuk memperoleh return tak normal (Jogiyanto, 214). Alasan mengapa perusahaan melakukan pemecahan saham kemungkinan dikarenakan harga saham yang terlalu tinggi sehingga saham tersebut relatif tidak likuid, jika saham relatif tidak likuid maka transaksi perdagangan terhadap saham tersebut akan semakin sedikit. Sedikitnya transaksi perdagangan yang terjadi menyebabkan harga relatif tidak bergerak fluktuatif, sehingga harapan untuk mendapatkan return tak normal juga akan semakin kecil.

Beberapa studi tentang pengaruh stock split terhadap volume perdagangan saham dan return tak normal telah dilakukan oleh para peneliti-peneliti terdahulu antara lain oleh Aduda and Chemarum (2010); Leung, et al (2005) hasil penelitian mereka menunjuukan bahwa pemecahan saham berpengaruh dan signifikan terhadap volume perdagangan saham dan return tak normal. Farinha and Basilio (2006) hasil penelitiannya menunjukkan bahwa pemecahan saham berpengaruh positif signifikan terhadap volume perdagangan tapi tidak signifikan terhadap return tak normal. Sedangkan Carlos \& Frank (2009), hasil penelitiannya menunjukkan bahwa pelaku pasar tidak merespon atas peristiwa stock split. Farinha dan Basilio (2006) hasil penelitiannya menunjukkan bahwa tidak ada peningkatan likuiditas saham setelah pemecahan yang ditunjukkan dari tidak adanya perbedaan yang signifikan pada rata-rata volume perdagangan saham. Lin, Singh, dan Yu (2008) dan Boehme dan Danielsen (2007) hasil penelitian mereka menyatakan bahwa pemecahan saham akan membuat saham lebih dapat dijangkau oleh investor kecil, dan pemecahan saham akan meningkatkan kecepatan perdagangan saham tersebut walaupun biaya transaksi menjadi lebih mahal. Menurut mereka, faktor kesulitan memperjualbelikan saham karena kemahalan harga menjadi salah satu faktor dalam melakukan pemecahan saham. Dengan pemecahan saham, harga saham menjadi lebih murah dan dapat dijangkau investor kecil. Walaupun biaya transaksi akan menjadi lebih mahal, namun karena kecepatan perdagangan saham meningkat, maka kemahalan biaya transaksi dapat tertutupi dengan adanya peningkatan kecepatan perdagangan saham tersebut. Berdasarkan uraian diatas nampak bahwa hasil - hasil penelitian terdahulu tentang pengaruh stock split terhadap volume perdagangan saham dan return tak normal masih memberikan hasil yang bervariasi, sehingga peneliti berusaha untuk mengkaji ulang tentang "Perbandingan abnormal return dan likuditas saham sebelum dan sesudah stock split: studi pada perusahaan yang terdaftar di Bursa Eefek Indonesia. Mengacu pada latar belakang masalah yang diuraikan di atas, maka tujuan penelitian adalah untuk mengetahui apakah terdapat perbedaan rata-rata abnormal return dan volume perdagangan saham sebelum dan sesudah stock split

\section{KAJIAN TEORI}

Pasar modal merupakan tempat investasi yang dapat memberikan potensi keuntungan bagi investor. Kegiatan pasar modal tidak terlepas dari tersedianya berbagai macam informasi tentang perusahaan. Informasi merupakan kebutuhan utama bagi para investor karena akan digunakan dalam pengambilan keputusan investasi. Salah satu informasi yang berpengaruh terhadap harga sekuritas adalah corporate action yang salah satunya adalah pemecahan saham. 
Pemecahan Saham (Stock Splits). Pemecahan saham atau stock splits adalah kegiatan memecah selembar saham menjadi beberapa lembar saham (n lembar saham) sehingga harga per lembar saham baru setelah stock splits adalah sebesar $1 / n$ dari harga sebelumnya. Pemecahan saham juga diartikan sebagai tindakan perusahaan untuk menaikkan jumlah saham yang beredar, seperti melipatgandakan jumlah saham yang beredar dengan menukar satu saham lama dengan dua saham baru, yang nilainya setengah dari nilai saham lama (Weston and Brigham, 1996). Tujuan perusahaan melakukan Stock Split adalah meningkatkan likuiditas saham di bursa dan memberikan investor kecil untuk bisa membeli saham karena harganya akan turun saat stock split” (Lin, Singh, dan Yu, 2008). Secara teoritis pemecahan saham dilatar belakangi oleh perusahaan melakukan pemecahan saham serta pengaruh yang ditimbulkan tertuang dalam beberapa teori. Di antaranya ada dua teori utama yang mendominasi literatur pemecahan saham, yaitu signaling theory dan trading theory.

Signaling Theory (Teori Sinyal). Signaling theory menyatakan bahwa stock split dianggap perusahaan memberikan sinyal yang baik kepada publik berkaitan dengan prospek perusahaan yang bagus dimasa depan, karena perusahaan yang melakukan pemecahan saham adalah perusahaan yang memiliki saham dengan harga yang tinggi, harga saham yang tinggi tersebutlah sebagai sinyal bahwa perusahaan memilik prospek masa depan yang baik, dimana harga saham yang tinggi mencerminkan bahwa perusahaan memiliki kinerja yang baik (Jogiyanto, 2014). Menurut Signaling theory, stock split hanya dilakukan oleh perusahaan yang memiliki prospek kinerja yang baik dimana perusahaan yakin bahwa harga saham setelah di pecah akan naik sesuai dengan kenaikan kinerja perusahaan di masa depan. Copeland (1979) dalam Jogiyanto (2014) menyatakan bahwa stock split memerlukan biaya transaksi yang besar, misalnya mencetak sertifikat baru sehingga perusahaan yang memiliki prospek yang baik saja yang mampu menaggung biaya tersebut. Jika bereaksi pada waktu pemecahan saham bukan berarti pasar bereaksi atas informasi pemecahan saham yang tidak memiliki nilai ekonomis, melainkan mengetahui prospek perusahaan di masa depan yang disinyalkan melalui pemecahan saham. Jadi faktor yang memotivasi perusahaan melakukan pemecahan saham adalah kinerja perusahaan.

Trading Range Theory. Perusahaan yang melakukan pemecahan saham karena harga sahamnya terlalu tinggi sehingga tidak mampu di jangkau oleh calon investor kecil. Menurut Trading Range Theory harga saham yang terlalu tunggi menyebabkan saham tidak likuid, hal tersebut berkaitan dengan kemampuan tiap - tiap investor yang berbeda - beda, oleh karena itu perusahaan melakukan pemecahan saham dalam upaya mengarahkan harga saham pada interval tertentu yang tidak terlalu mahal. Fahmi (2010) menyatakan bahwa dengan melakukan pemecahan saham harga saham menjadi tidak terlalu tinggi sehingga mampu dijangkau oleh calon investor dan pada akhirnya meningkatkan likuiditas saham. Sehingga menurut trading range theory, perusahaan melakukan stock split karena memandang harga sahamnya terlalu tinggi, dengan kata lain harga saham yang terlalu tinggi itulah yang mendorong perusahaan melakukan pemecahan saham.

Event Study (Studi Peristiwa). Studi peristiwa merupakan studi yang mempelajari reaksireaksi pasar terhadap suatu peristiwa yang informasinya telah dipublikasikan. Reaksi ini dapat diukur dengan menggunakan return sebagai nilai perubahan harga atau dengan menggunakan return tidak normal. Jika digunakan return tidak normal maka dapat 
dikatakan bahwa suatu pengumuman yang mempunyai kandungan informasi akan memberi abnormal return kepada pasar. Sebaliknya yang tidak mengandung informasi tidak memberikan abnormal return kapada pasar. Kandungan informasi yang ada kemudian diuji yang dimaksudkan untuk melihat reaksi suatu pengumuman. Jika pengumuaman mengandung informasi maka diharapkan pasar akan bereaksi melalui pengumuman yang diterima. Reaksi pasar ditunjukkan dengan adanya perubahanperubahan dari sekuritas yang bersangkutan, misalnya tercermin dari perubahan harga, volume perdagangan saham dan abnormal return (Jogiyanto, 2010)

Likuiditas Saham. Likuiditas saham adalah ukuran jumlah transaksi saham di pasar modal dalam satu periode tertentu. Semakin tinggi frekuensi transaksi saham maka semakin tinggi likuiditas saham, ini berarti saham tersebut semakin diminati oleh para investor dan hal tersebut akan meningkatkan harga saham yang bersangkutan. Pada kenyataannya tidak semua saham mudah ditransaksikan atau dengan kata lain mengalami kesulitan likuiditas. Saham yang relatif tidak likuid dapat dikenakan deslisting atau dikeluarkan dari Pasar Modal. Suatu saham dikatakan likuid bila saham tersebut mudah untuk ditukarkan atau dijadikan uang. Semakin likuid suatu saham berarti jumlah atau frekuensi transaksi semakin tinggi. Hal tersebut juga menunjukkan minat investor untuk memiliki saham tersebut juga tinggi. Minat yang tinggi dimungkinkan karena saham yang likuiditasnya tinggi memberikan kemungkinan yang lebih tinggi untuk memperoleh return dibandingkan saham yang likuiditasnya lebih rendah sehingga tingkat likuiditas saham biasanya akan mempengaruhi harga saham yang bersangkutan. Likuiditas secara sederhana, menunjukkan kemudahan untuk menjual dan membeli efek pada harga yang wajar. Jadi jika untuk menjual dan membeli sejumlah tertentu saham harus menunggu atau kalau spread antara permintaan dan penjualan relatif besar, atau penjualan saham dalam jumlah relatif besar akan mempengaruhi harga pasar secara substansial, bisa dikatakan bahwa saham tidak likuid. Pemecahan saham sebagai suatu aksi dilakukan oleh perusahaan, juga memuat informasi diasumsikan akan mempengaruhi keputusan jual beli yang dilakukan oleh investor, yang pengaruh tersebut dapat dilihat dalam aktivitas perdagangan dalam keputusan investasinya. Atas dasar pemikiran-pemikiran di atas dapat disimpulkan sementar bahwa pemecahan saham akan mempengaruhi likuiditas saham. Meskipun pengaruh tersebut belum dapat diketahui apakah bersifat positif atau negatif dalam arti pemecahan saham meningkatkan atau menurunkan likuiditasnya. Semakin cepat suatu asset dapat berubah menjadi uang maka semakin tinggi likuiditasnya. Salah satu daya tarik agar suatu saham diminati investor adalah harga yang relatif murah serta rendahnya biaya komisi transaksi. Menurut Tandelilin (2010) bahwa salah satu parameter yang sering digunakan untuk mengukur tingkat likuiditas suatu saham adalah melalui volume perdagangan saham.

Return Saham dan Abnormal Return. Motivasi utama investor untuk menginvestasikan modalnya dalam suatu investasi adalah mendapatkan tingkat pengembalian investasi yang optimal. Return merupakan tingkat keuntungan yang dinikmati investor atas suatu investasi yang dilakukannya (Jogiyanto, 2014). Return saham yang akan diterima oleh investor sangat dipengaruhi oleh jenis investasi yang dipilih. Untuk mengukur besarnya return yang akan diterima investor sehubungan dengan adanya peristiwa pemecahan saham diukur dengan adanya abnormal return yang diterima oleh investor. Abnormal return merupakan selisih antara return yang sebenarnya (Actual Return) dengan return yang diharapkan (Expected Return). Tingkat keuntungan yang sesungguhnya merupakan 
perbandingan antara selisih harga saham periode sekarang dengan periode sebelumnya. Return yang tidak normal yang positif menunjukkan tingkat keuntungan yang diperoleh lebih besar yaitu antara actual return dan expected return. Berkaitan dengan peristiwa pemecahan saham, apabila terjadi abnormal return yang positif setelah pemecahan saham dapat memberikan keuntungan diatas normal pada investor dan sebaliknya jika terdapat abnormal return yang negatif menunjukkan bahwa keuntungan yang diperoleh dibawah normal. Uji efisiensi pasar modal yaitu dengan menganalisis return yang tidak normal yang terjadi. Abnormal return merupakan kelebihan dari return yang sesungguhnya terjadi terhadap return normal. Studi peristiwa merupakan analisis return tidak normal (abnormal return) dari sekuritas yang mungkin terjadi disekitar pengumuman dari suatu peristiwa. Dengan demikian return tidak normal (abnormal return) adalah selisih antara return sesungguhnya yang terjadi dengan return ekspektasi yang dirumuskan sebagai berikut:

$$
\mathrm{AR} \text { it }=\mathrm{R} \text { it }-\mathrm{E}(\mathrm{R} \text { it })
$$

Dimana: AR it : return tidak normal saham i pada periode peristiwa ke- $\mathrm{t}$; $\mathrm{R}$ it : return sesungguhnya yang terjadi untuk saham ke i pada periode peristiwa ke- t; E (R it ) : expected return saham ke i untuk periode peristiwa ke- $t$

Actual return (return sesungguhnya) merupakan keuntungan yang dapat diterima atas investasi saham pada suatu periode tertentu, secara matematis dapat dirumuskan sebagai berikut:

$$
\text { Rit }=\frac{\text { Pit }- \text { Pit }-1}{\text { Pit }-1}
$$

Dimana: R it : return saham i pada hari ke- t; Pit : harga saham i pada hari ke- t ; Pit -1 : harga saham i pada hari t-1

Menurut Jogiyanto (2014) bahwa untuk mengestimasi expected return dapat menggunakan beberapa model estimasi antara lain:

a. Mean adjusted model. Model disesuaikan rata-rata (mean adjusted model) menganggap bahwa return ekspektasi bernilai konstan yang sama dengan rata-rata return realisasi sebelumnya selama periode estimasi. Model ini dapat dirumuskan sebagai berikut:

$$
\mathrm{E}(\mathrm{R} \text { it })=\frac{\sum R_{i j}}{T}
$$

Dimana:

$\mathrm{E}(\mathrm{R}$ it $)=$ return ekspektasi sekuritas ke-i pada periode peristiwa ke-t.

$\mathrm{R}$ ij = return realisasi sekuritas ke-i pada periode estimasi ke-j.

$\mathrm{T}=$ lamanya periode estimasi yaitu dari $\mathrm{t} 1 \mathrm{-t} 2$.

b. Market model. Perhitungan return ekspektasi dengan model ini dilakukan dengan 2 tahap:

Pertama. Perhitungan return ekpektasi ke-i pada periode estimasi.

Kedua. Menggunakan model ekpektasi dapat dibentuk dengan menggunakan teknik regresi OLS (Ordinary Least Square) dengan persamaan sebagai berikut :

$$
R i j=\alpha i+\beta i R M j+E i j
$$


Dimana : $\mathrm{Rij}=$ return realisasi sekuritas ke-i pada periode estimasi ke-j; $\alpha \mathrm{i}=$ intercept untuk sekuritas ke-i; $\beta \mathrm{i}=$ koefisien slope yang merupakan beta sekuritas ke-i; $\mathrm{RMj}$ = return indeks pasar pada periode estimasi ke-j; Eij = kesalahan residu ke-i pada periode estimasi ke-j.

c. Market adjusted model. Model ini menganggap bahwa penduga terbaik untuk mengestimasi return suatu sekuritas adalah return indeks pasar pada saat tersebut. Dengan menggunakan model ini maka tidak perlu menggunakan periode estimasi untuk membentuk model estimasi, karena return sekuritas yang diestimasi adalah sama dengan return pasar.

$$
\mathrm{E}(\mathrm{R} \text { it })=\mathrm{Rmt}
$$

Dimana : E (R it ) = return ekspektasi sekuritas ke-i pada periode peristiwa ke-t; Rmt $=$ return sekuritas pada waktu ke $-\mathrm{t}$.

Pengaruh Pemecahan Saham Terhadap Volume Perdagangan Saham. Volume perdagangan saham salah satu indikator yang digunakan untuk melihat reaksi pasar terhadap kejadian atau informasi yang berkaitan dengan suatu saham. Perubahan volume perdagangan diukur dengan aktivitas volume perdagangan saham yang diukur dengan Trading Volume Activity. TVA merupakan perbandingan antara jumlah saham yang diperdagangkan pada waktu tertentu dengan jumlah saham perusahaan yang beredar pada periode tertentu. Besar kecilnya perubahan rata-rata TVA antara sebelum dan sesudah pemecahan saham merupakan ukuran besar kecilnya akibat yang ditimbulkan oleh adanya pemecahan saham terhadap volume perdagangan saham. Pemecahan saham yang digunakan oleh perusahaan ketika harga sahamnya dinilai terlalu tinggi akan mempengaruhi kemampuan investor untuk membelinya akan mempunyai nilai jika terdapat perubahan dalam volume perdagangan sahamnya. Besar kecilnya pengaruh pemecahan saham terhadap volume perdagangan saham terlihat dari besar kecilnya jumlah saham yang diperdagangkan. Sehubungan dengan adanya pemecahan saham maka harga saham akan menjadi lebih murah sehingga volatilitas harga saham menjadi lebih besar dan akan menarik investor untuk memiliki saham tersebut atau menambah jumlah saham yang diperdagangkan. Menurut Weston dan Copeland dalam Jogiyanto (2014) bahwa semakin banyak investor yang akan melakukan transaksi terhadap saham tersebut maka volume perdagangan sahamnya juga akan meningkat.

Pengaruh Pemecahan Saham Terhadap Return Saham. Aksi yang dilakukan oleh perusahaan berupa pemecahan saham dapat ditafsirkan sebagai sinyal yang diberikan oleh perusahaan tentang adanya prospek yang bagus dimasa yang datang, dimana harga saham yang tinggi merupakan suatu indikator bahwa kinerja perusahaan bagus, selain itu harga saham yang menjadi lebih murah menyebabkan banyaknya transaksi yang akan dilakukan sehingga harga saham cenderung menjadi berubah dan dapat memberikan peluang untuk memperoleh abnormal return bagi investor. Abnormal return ini akan dihitung dengan selisih antara actual return dan expected return, dimana actual return merupakan perbandingan harga saham hari ini dengan harga saham sebelumnya secara relatif. Sedangkan expected return dihitung dengan return pasar yang dikalikan dengan beta masing-masing perusahaan ditambah dengan alpha masing-masing perusahaan. Abnormal return saham yang diperoleh setelah melakukan pemecahan saham terjadi penurunan, hal 
ini berakibat pada abnormal return yang diperoleh bernilai negatif karena actual return yang diperoleh lebih rendah dibanding expected return.

\section{METODE}

Tempat dan Waktu Penelitian. Penelitian ini merupakan penelitian yang termasuk ke dalam kategori event studies atau studi peristiwa. Studi peristiwa adalah studi yang mempelajari reaksi pasar terhadap suatu peristiwa yang informasinya dipublikasikan sebagai suatu pengumuman. Penelitian ini dilakukan di Bursa Efek Indonesia. Sedangkan periode pengamatan yang dilakukan adalah untuk jangka waktu empat tahun yakni tahun 2011-2014

Objek Penelitian. Adapun objek penelitian ini adalah stock split, abnormal return dan volume perdagangan saham pada beberapa perusahaan yang listing di Bursa Efek Indonesia. Variabel-variabel yang diidentifikasi dalam penelitian dapat dikelompokkan sebagai berikut:

Stock splits. Penetapan tanggal dimana stock split diumumkan kepada publik melalui Bursa Efek Indonesia (BEI) disebut juga dengan tanggal pengumuman stock split (event date). Tanggal diumumkannya pemecahan saham digunakan sebagai $\mathrm{t}=0$. Adapun periode pengamatan (event window) dalam penelitian ini adalah selama 5 hari, yaitu 5 hari sebelum pemecahan saham dan 5 hari setelah pemecahan saham. Pemilihan periode pengamatan tersebut dipilih dengan mempertimbangkan bahwa peristiwa pemecahan saham merupakan peristiwa dimana nilai ekonomisnya dengan mudah dapat ditentukan oleh investor, sehingga investor berreaksi dengan cepat dan tepat serta untuk menghindari terjadinya confounding effect yaitu dampak tercampurnya suatu peristiwa dengan peristiwa lain

Volume Perdagangan saham. Jumlah saham yang diperdagangkan dalam periode tertentu disebut juga dengan volume perdagangan saham dimana volume perdagangan saham diukur dengan Trading Volume Activity. Dimana untuk mengukur besarnya Trading Volume Activity yaitu dengan cara membandingkan jumlah saham perusahaan yang diperdagangkan dalam periode tertentu dengan jumlah saham perusahaan yang beredar pada periode tertentu. Kemudia, rata-rata masing-masing volume perdagangan saham antara sebelum dan sesudah pemecahan saham dihitung untuk mengetahui perbedaan. Untuk mengetahui signifikan atau tidaknya digunakan statistik uji beda dua rata-rata TVA sebelum dan sesudah pemecahan saham. Sedangkan rumus yang digunakan adalah sebagai berikut:

TVA $=\frac{\text { Jumlah saham perusahaan } \mathrm{i} \text { yang diperdagangkan pada periode tertentu }}{\text { Jumlah saham perusahaan i yang diperdagangkan pada waktu tertentu }}$

Abnormal Return. Return saham merupakan keuntungan yang diperoleh para investor atas apa yang telah diinvestasikannya. Besarnya return saham dapat terlihat dari adanya abnormal return yang diperoleh investor berkaitan dengan adanya peristiwa pemacahan saham. Abnormal return adalah selisih dari expected return dengan actual return $(\mathrm{AR}=\mathrm{Rit}$ - ER), sedangkan actual return adalah selisih antara harga sekarang dengan harga 
sebelumnya secara relatif. Kemudian dihitung besarnya rata-rata abnormal return saham sebelum dan sesudah peristiwa pemecahan saham. Untuk mengetahui signifikan atau tidaknya dilakukan dengan statistik uji beda dua rata - rata abnormal return sebelum dan sesudah pemecahan saham.

Perhitungan abnormal return penelitian ini dengan menggunakan model yang disesuaikan-pasar yaitu market adjusted model. Abnormal return merupakan selisih antara tingkat keuntungan yang sebenarnya (actual return) dengan tingkat keuntungan yang diharapkan (expected return). Pada model ini menganggap bahwa penduga paling baik untuk return suatu sekuritas adalah return indeks pasar pada saat itu. Jika return indeks pasar pada saat pengumuman adalah $17 \%$ maka expected return semua sekuritas pada saat yang sama adalah sama dengan return indeks pasarnya yaitu 17\%. Jika return suatu sekuritas pada saat yang sama sebesar 35\% maka abnormal return untuk sekuritas tersebut adalah 18\% (35\% - 17\%) (Jogiyanto,2014).

Adapun rumus yang digunakan adalah market adjusted model sebagai berikut :

$$
\text { ARit }=\text { Rit }- \text { ER }
$$

Kerangan: ARit $=$ abnormal return saham $\mathrm{i}$ pada hari ke $\mathrm{t}$; Rit $=$ actual return saham $\mathrm{i}$ pada hari ke t; ER = expected return pasar pada hari ke t.

Untuk menghitung abnormal return dilakukan langkah-langkah sebagai berikut

a. Menghitung actual return. Actual return saham yang diperoleh dengan mencari selisih antara harga sekarang dikurangi dengan harga saham hari sebelumnya dibagi harga saham hari sebelumnya. Menghitung actual return untuk mengetahui perbandingan harga saham hari ini dengan harga saham pada hari sebelumnya digunakan persamaan sebagai berikut:

$$
\mathrm{Rit}=\frac{P_{i t-} P_{i t-1}}{P_{i t-1}}
$$

Dimana: Rit : Return saham i pada waktu t; Pit : Harga saham i pada waktu t; Pit-1 : Harga saham t pada waktu t-1

b. Menghitung expected return. Expected return dihitung dengan mengunakan indeks pasar karena menurut market adjusted model penduga terbaik untuk mengestimasi return suatu sekuritas adalah indeks pasar pada saat hari itu. Maka dengan model ini tidak perlu menggunakan estimation period karena return efek yang diestimasi sama dengan return indeks pasar. Indeks pasar yang digunakan adalah IHSG. Maka untuk menghitung expected return digunakan rumus sebagai berikut.

$$
\mathrm{ER}=\frac{I H S G_{t}-I H S G_{t-1}}{I H S G_{t-1}}
$$

Dimana: ER = expected return ; IHSGt = Indeks Harga Saham Gabungan pada hari ke $\mathrm{t}$ IHSGt-1 = Indeks Harga Saham Gabungan pada hari ke t-1

Populasi dan Sampel. Populasi dalam penelitian ini adalah seluruh perusahaan yang telah melakukan stock split periode tahun 2011-2014 yakni sebanyak 43 perusahaan. Teknik Pemilihan sampel dengan menggunakan metode purposive sampling dengan kriteria: 
perusahaan yang melakukan stock split dengan jenis split up, perusahaan masih terdaftar di Bursa selama satu tahun setelah peristiwa stock split, dan perusahaan memiliki kelengkapan data yang diperlukan dalam penelitian. Dengan kriteria tersebut, maka diperoleh 24 perusahaan yang memenuhi kriteria dijadikan sampel.

Jenis Dan Sumber Data. Jenis data yang digunakan dalam penelitian ini adalah data sekunder, karena tidak memungkinkan untuk memperoleh data tersebut secara langsung. Data sekunder merupakan data yang diperoleh dari pihak lain yang dipublikasikan dalam bentuk yang sudah jadi. Jenis data dalam penelitian ini adalah data kuantitatif dan kualitatif. Data diperoleh dari www.britama.com, www.idx.co.id, www.yahoofinance.com

Metode Pengumpulan Data. Penelitian ini menggunakan metode pengumpulan data bahan dokumen yang didapat dari uraian-uraian seperti buku,internet, karya ilmiah berupa jurnal, serta dokumen-dokumen lainnya yang berkaitan dengan penelitian,

Metode Analisis. Untuk menguji hipotesis dalam penelitian ini menggunakan analisis uji beda dua rata-rata. Pengujian dengan cara ini menggunakan metodologi studi peristiwa. Untuk menguji hipotesis dalam penelitian ini menggunakan analisis uji beda dua rata rata (t-test). Sebelum dilakukan pengujian hipotesis terlebih dahulu dilakukan pengujian normalitas data dengan maksud untuk mengetahui apakah sampel yang digunakan dalam penelitian ini adalah berdistribusi normal atau tidak.Untuk mendeteksi normalitas data dapat dilakukan dengan uji metode kolmogorov-smirnov test. Data berdistribusi normal apabila nilai probabilitas $>0,05$ sebaliknya jika nilai probabilitas $\leq 0,05$ maka data berdistribusi tidak normal. Kemudian setelah itu akan dilakukan pengujian dengan uji Beda:

Uji beda dilakukan untuk membuktikan apakah pemecahan saham mempunyai pengaruh yang signifikan terhadap abnormal return pada sebelum dan sesudah pemecahan saham dengan teknik analisisi sebagai berikut. (1) One Sample $t$ Test. Apabila data berdistribusi secara normal maka pengujian dengan menggunakan One Sample t Test; (2) Wilcoxon Signed Ranks Test. Apabila data berdistribusi tidak normal maka pengujian dilakukan dengan menggunakan pengujian non-parametik yaitu uji wilcoxon signed ranks test.

\section{HASIL DAN PEMBAHASAN}

Hasil pengujian normalitas. Setelah dilakukan uji normalitas Kolmogorov-Smirnov untuk mengetahui apakah data masing-masing variable abnormal return dan volume perdagangan saham sebelum dan sesudah stock splits terdistribusi normal atau tidak hasilnya dapat dilihat pada Tabel 1 berikut.

Tabel 1. One-Sample Kolmogorov-Smirnov Test

\begin{tabular}{lllll}
\hline & & ARR & TVA & \\
& ARR Sebelum & Sesudah & Sebelum & TVA Sesudah \\
\hline $\mathrm{N}$ & 24 & 24 & 24 & 24 \\
Test Statistic & .337 & .379 & .403 & .361 \\
Asymp. Sig. (2-tailed) & .000 & .000 & .000 & .000 \\
\hline
\end{tabular}

Sumber: data diolah penulis 
Dari Tabel 1 di atas nampak bahwa abnormal return dan volume perdagangan saham sebelum dan sesudah stock splits berdistribusi tidak normal yang ditunjukkan dengan nilai Sig. pada semua variabel (sebelum dan sesudah stock splits) $<0,05$, maka pengujian selanjutnya perbandingan return tidak normal dan lukiditas saham sebelum dan sesudah pemecahan saham akan menggunakan uji non parametrik wilcoxon signed ranks test.

Hasil pengujian variable abnormal return sebelum dan sesudah stock split dapat dilihat pada Tabel 2 berikut:

Tabel 2. Uji Statistik Abnormal Return

\begin{tabular}{lr}
\hline & $\mathrm{ARR}_{1}-\mathrm{ARR}_{2}$ \\
$\mathrm{Z}$ & $-1.686^{\mathrm{b}}$ \\
Asymp. Sig. (2-tailed) & .092 \\
\hline Sumber: data diolah penulis &
\end{tabular}

Berdasarkan Tabel 2 di atas nampak bahwa nilai asymp. Sig.(2-tailed) $=0$,092, hal ini menunjukan bahwa dengan taraf nyata $(\alpha) 10$ persen terdapat perbedaan yang signifikan rata-rata abnormal return sebelum dan sesudah stock split. Hasil penelitian ini mendukung signalling theory yang menyatakan bahwa pengumuman stock split ialah salah satu corporate action yang dilakukan perusahaan, dimana perusahaan dapat menggunakan stock split untuk memberikan sinyal positif kepada pasar tentang ekspektasinya di masa mendatang. Stock split mempunyai kandungan informasi, sehingga para investor langsung bereaksi dalam mengambil keputusan untuk berinvestasi. Penelitian ini sesuai dengan hasil penelitian dari: Josphura (2008); Aduda dan Caroline (2010); Griffin (2010), tetapi tidak mendukung hasil penelitin dari: Carlos and Frank (2009); Boehme dan Danielsen, (2007) Chakraborty (2011).

Hasil pengujian variable volume perdagangan saham sebelum dan sesudah stock split dapat dilihat pada Tabel 3 berikut.

Tabel 3. Uji Satistik Volume Perdagangan Saham

\begin{tabular}{lr}
\hline & TVA $_{2}-\mathrm{TVA}_{1}$ \\
\hline $\mathrm{Z}$ & $-1.972^{\mathrm{b}}$ \\
Asymp. Sig. (2-tailed) & .049 \\
\hline Sumber: data diolah penulis &
\end{tabular}

Berdasarkan Tabel 3 di atas nampak bahwa nilai asymp. Sig.(2-tailed) =0,049, hal ini menunjukan bahwa pada taraf nyata $(\alpha) 5$ persen terdapat perbedaan yang signifikan pada volume perdagangan saham sebelum dan sesudah pemecahan saham. Volume perdagangan saham merupakan indikator yang dapat menyatakan tinggi rendahnya likuiditas saham suatu perusahaan. Suatu saham dikatakan likuid bila saham sering diperdagangkan. Dengan pemecahan saham dimana harga saham menjadi lebih rendah, para investor akan tertarik untuk membeli saham tersebut sehingga saham menjadi lebih likuid. sehingga saham tersebut menjadi lebih likuid untuk di perdagangkan. Hasil penelitian ini sejalan penelitian yang telah dilakukan oleh Leung (2005); Josphira (2008); Alex et al. (2011); Rudnicki (2012); Aduda dan Caroline, (2010) serta Goyenko, Ukhov dan Holden (2009) serta sejalan dengan trading range theory yang menyatakan bahwa stock split merupakan corporate action yang dilakukan perusahaan untuk menurunkan harga saham perusahaanya yang terlalu tinggi serta diharapkan dapat mengatur kembali harga saham pada kisaran harga yang setara dengan harga pasar perusahaan sejenis 
lainnya sehingga terjangkau oleh para investor, tetapi tidak mendukung temuan Guo, et al, (2009); Boehme dan Danielsen, (2007).

\section{PENUTUP}

Simpulan. Dari hasil penelitian dan pembahasan menunjukkan bahwa dengan alpha 10 persen adanya perbedaan yang signifikan rata-rata abnormal return sebelum dan sesudah stock split, hal ini menunjukkan bahwa stock split memiliki kandungan informasi sehingga langsun direspon oleh investor atau investor menganggap bahwa peristiwa stock split adalah good news, sehingga mengubah preferensi investor terhadap keputusan investasinya. Dengan alpha 5 persen adanya perbedaan yang signifikan rata-rata likuiditas saham sebelum dan sesudah stock split, hal ini menunjukkan bahwa tujuan perusahaan melakukan stock split yaitu untuk mengatur kembali harga saham pada kisaran harga yang sebanding dengan harga pasar perusahaan sejenis lainnya sehingga terjangkau oleh investor dapat tercapai sejalan dengan hasil yang didapatkan dari penelitian ini.

Saran. Bagi investor, apabila menginginkan harga lebih rendah pada saat membeli saham, dapat berinvestasi pada perusahaan yang akan melakukan stock split dengan harapan mendapatkan keuntungan (capital gain) dari selisih harga saham, sehingga perlu menjadikan pengumuman stock split sebagai informasi yang positif dalam proses transaksi saham di Bursa Efek Indonesia. Bagi perusahaan, hasil penelitian ini perlu dijadikan salah satu bahan pertimbangan dalam pengambilan keputusan untuk melakukan stock split, karena hasil yang diperoleh menyatakan bahwa stock split mampu mengubah preferensi investor dalam bertransaksi sehingga perusahaan dapat memberikan sinyal baik kepada calon investor dan diharapkan prospek perusahaan di masa mendatang akan lebih baik.

\section{DAFTAR RUJUKAN}

Aduda, Josiah Omolo and Chemarum Caroline S.C, (2010) "Market Reaction to Stock Splits Empirical Evodance From The Nairobi Stock Exchange”, Afican Journal Of Business \& Management. Vol 1: 165-184

Alex, Dhanya., Pavithran \& Eapen Rohit Paul. (2011) "Price and Liquidity Chages After Stock Split-Empirical Evidence From Indian Stock”. International Journal of Research in Commerce, It \& Management, 1 (2): 45-50

Boehme, R.D. \& Danielsen, B.R. (2007) "Stock-Split Post-Announcement Returns: Under reaction or Market Friction?”, The Financial Review, 42 (4): 485506.

Brigham, Eugene F. dan I.C. Gapenski. (1996) Intermediate Financial Managememt. Fifth Edition. New York: The Dryden Press.

Carlos, Garcia de Andoain and Frank W. Bacon. (2009) The Impact of StockosplitAnnouncement on Stock Price: A Test of Market Efficiency.Proceeding bofh American Society nofh Business and Behaviorali sciences Annual Conference, Lasd Vegas, 16 (1):1-14.

Chakraborty, Prithul. (2011) "Semi-Strong Form of Pricing Efficiency of Indian Stock Market - An Empirical Test in The Context Of Stock-Split Announcements". International Journal of Multidisciplinary Management Studies, 1 (2): 1-13

Fahmi, Irham. (2012) Manajemen Investasi, Jakarta: Salemba Empat 
Farinha, Jorgen \& Nunon Filipen Basílio. (2006) Stock Splits: Real Effects or Just a Question of Maths? An Empirical Analysis of the Portuguese Case. Centro de Estudos de Economia Industrial, 2 (8): 1-54

Goyenko, R.Y., Holden, C.W., \& Ukhov, A.D. (2009) Do Stock Splits Improve Liquidity?, Working Paper. Indiana University fromwww.ssrn.com

Griffin, Carroll Howard. (2010) "Abnormal Returns and Stock Splits: The Decimalized vs Fractional System of Stock Price Quotes”. International Journal of Business and Management, 5 (12): 3-13

Guo, Fang \&Zhou, Kaiguo. (2006) "Stock splits, liquidity, and information asymmetryAn empirical study on Tokyo Stock Exchange". Journal of Economics and Finance. China.

Howard, Caroll. (2010) "Abnormal Returns and Stock Splits: The Decimalized vs. Fractional System of Stock Price Quotes”. International Journal of Business and Management,11: 1-11

Hua, Liu \& Skanthavthar Ramesh. (2013) "A Study on Stock Split Announcements and Its Impact on Stock Prices in Colombo Stock Exchange (CSE) of Sri Lanka”. Global Journals Inc. (USA), 13 (6): 25-34

Jaelani. (2013) "Stock Split Policy on Signal and Liquidity Motive with Implications to Retail Investor". International Journal of Science and Research , 2(6): 426-431

Jogiyanto Hartono. (2014) Teori dan Analisis Investasi. Edisi Kesembilan. Yogyakarta: BPFE.

Jogiyanto, Hartono. (2010 Studi Peristiwa: Menguji Reaksi Pasar Modal Akibat Suatu Peristiwa. Yogyakarta: BPFE

Joshipura, Mayank. (2008) Price and Liquidity Effect of Stock split: An Empirical Evidence From Indian Stock Market. NSE Research Initiative, pp: 1-20.

Leung, Tak Yan, et al, (2005) Do Stock Splits Really Signal ? “, pp. 1 - 33.

Lin, J.C., Singh, A.K., \& Yu, W. (2008) "Stock Splits and The Trading Speed Improvement Hypothesis". Working paper Social Science Research Network Journal. www.ssrn.com, 1-45

Louis, H. and Robinson, D. (2003) "Do Managers credibly use Accruals to Signal Private Information? Evidence from the Pricing of Accruals around Stock Splits”, Journal of Finance.

Menendez, Susana and Silvia Gomez - Anson. (2003) Stock Splits: Motivationsand Valuation Effects In The Spanish Market. Investigaciones Economicas, pp. 459 490.

Reilly and Brown. (2006) Investment Analysis and Portofolio Management. USA: The Dryden Press Hacouft Brace Collage.The Impact of Share Split for Share Return

Rudnicki, Jozef. (2012) Stock Splits And Liquidity For Two Major Capital Markets From Central - Eastern Europebusiness. Management And Education, 10 (2), pp: 145158

Tandelilin, Eduardus. (2010) Portofolio dan Investasi: Teori dan Aplikasi. Yogyakarta: Kanisius 